\title{
GROWTH, PRODUCTION AND QUALITY OF PINEAPPLE IN RESPONSE TO HERBICIDE USE ${ }^{1}$
}

\author{
LEONARDO CARVALHO BRANT MAIA², VICTOR MARTINS MAIA ${ }^{3}$, \\ MÁRIO HENRIQUE MELO E LIMA ${ }^{3}$, IGNACIO ASPIAZÚ3 ${ }^{3}$, RODINEI FACCO PEGORARO ${ }^{4}$
}

\begin{abstract}
In pineapple fields, weed competition is exacerbated by the fact that the crop is small and has a very slow vegetative development. The objective of this study was to determine the effects of herbicides on growth, yield and quality of pineapple, cultivar 'Pérola'. The experimental design was in randomized blocks with four treatments and four replications. Treatments consisted of weeding by hoe and the herbicides diuron; fluazifop-p-butyl and atrazine + S-metolachlor applied in post-emergence. The characteristics evaluated monthly during the vegetative stage were stem diameter, D-leaf length, number of leaves, number of emitted leaves and percentage of natural floral induction. In the reproductive phase, evaluations were made of average fruit weight (g) with and without crown, fruits length and diameter, number of slip, slip-sucker and sucker type seedlings, determination of soluble solids and $\mathrm{pH}$ in the pulp. There was no effect of herbicide treatment on the vegetative growth characteristics. Stem diameter increased until 330 days after planting, showing a decrease after this period. The D-leaf grew over time in all treatments, although phytotoxicity symptoms were observed after the first application of herbicides. The traits evaluated on the reproductive phase showed no significant differences in response to treatments. Therefore, the use of diuron fluazifop-p-butyl and atrazine + S-metolachlor did not affect growth, yield and fruit quality of pineapple, cultivar 'Pérola'.
\end{abstract}

Index terms: Ananas comosus var. comosus, weeds, herbicides, 'Pérola'.

\section{CRESCIMENTO, PRODUÇÃO E QUALIDADE DO ABACAXIZEIRO EM RESPOSTA AO USO DE HERBICIDAS}

\begin{abstract}
RESUMO - No cultivo do abacaxizeiro, a competição com plantas daninhas é agravada pelo fato de a cultura apresentar pequeno porte e ter o desenvolvimento vegetativo muito lento. O objetivo do trabalho foi determinar os efeitos de herbicidas sobre o crescimento, a produtividade e a qualidade do abacaxizeiro 'Pérola'. O delineamento experimental foi em blocos casualizados com quatro tratamentos e quatro repetições. Os tratamentos foram constituídos de capina manual através de enxada e herbicidas diuron, fluazifpo-Pbutílico e Atrazina + S-Metalacloro em pós-emergência. As características avaliadas mensalmente na fase vegetativa foram diâmetro do talo, comprimento da folha " $\mathrm{D}$ ”, número de folhas, número de folhas emitidas e porcentagem de indução floral natural. Na fase reprodutiva, foram avaliados peso médio dos frutos (g) com e sem coroa, comprimento e diâmetro dos frutos, número de mudas do tipo filhote, filhote-rebentão e rebentão, determinação dos sólidos solúveis e ph da polpa. Não houve efeito dos tratamentos de aplicação de herbicidas sobre as características de crescimento vegetativo. O diâmetro do talo apresentou aumento até 330 dias após o plantio, evidenciando diminuição após esta época. A folha " $D$ " apresentou crescimento ao longo do tempo em todos os tratamentos embora tenham sido observados sintomas de fitotoxidez após a primeira aplicação dos herbicidas. As características avaliadas da fase reprodutiva não apresentaram diferença significativa em resposta aos tratamentos utilizados. Portanto, o uso de diuron, fluazifpo-P-butílico e Atrazina + S-Metolacloro não influenciaram o crescimento, a produção e a qualidade dos frutos do abacaxizeiro cultivar Pérola.
\end{abstract}

Termos de Indexação: Ananas comosus var. comosus, plantas daninhas, herbicidas, Pérola.

${ }^{1}$ (Trabalho 075-12). Received for publication on 31-01-2012.Revised form on 25-07-2012.

${ }^{2}$ Agronomist, Masters in Plant Production in the Semiarid of the Universidade Estadual de Montes Claros, Campus de Janaúba-MG, Av. Reinaldo Viana 2630, Bico da Pedra, 39440-000. E-mail: leobrantmaia@hotmail.com

${ }^{3}$ Agronomist, D.Sc. Professor of Higher Education of the Universidade Estadual de Montes Claros, Campus de Janaúba-MG, Av. Reinaldo Viana 2630, Bico da Pedra, 39440-000. E-mails: victor.maia@unimontes.br; ignacio.aspiazu@unimontes.br; rodinei.pegoraro@unimontes.br

${ }^{4}$ Scholar of Agronomy of the Universidade Estadual de Montes Claros, Campus de Janaúba-MG, Av. Reinaldo Viana 2630, Bico da Pedra, 39440-000. mhenriquelima@hotmail.com 


\section{INTRODUCTION}

Pineapple (Ananas comosus var. comosus (L.) Merril) belongs to the bromeliaceae, monocotiledonae family, originated from warm climates in the Americas, being the main producers: Thailand, Brazil, Philippines, India and China. Brazil is actually the second main pineapple producer, being Thailand the main producer (FAO, 2010). In Brazil, the main producing states are Pará, Paraíba and Minas Gerais (IBGE, 2011) .Cultivars most grown in Brazil are 'Pérola' and 'Smooth Cayenne' (CRESTANI, 2010). Between the two cultivars, 'Pérola' is the most planted due to its good acceptance on the domestic market and its pleasant taste, being the ideal cultivar for fresh fruit consumption.

According to Reinhardt (2002), pineapple shows slow growth and superficial root system, factors that expose it to intense competition with weeds, and contribute to delay crop development and reduce their yield and quality. It is recommended to keep the fields clean from weeds during the first five to six months after planting.

In pineapple fields, weed competition is exacerbated by the fact that the crop is small and grows very slowly, favoring the extraction of water and nutrients by weeds. (CATUNDA et al., 2005)

One of the alternatives to control competition is the use of herbicides, which allows less reliance on manpower. During the crop cycle, ten to twelve weedings may be needed, burdening the production cost considerably.

Weed control with herbicides is a good alternative, especially in large fields and rainy periods, when the grass grows quickly and hand hoe weeding is not feasible. It is important to accomplish the application carefully to avoid the pineapple to suffer phytotoxicity due to chemical products. (REINHARDT, 2001).

Diuron and atrazine are inhibitors of electron transfer in photosystem II. The fluazifop-p-butyl, an inhibitor of the ACCase enzyme, found in plastids stoma, converts acetyl-CoA into malonyl-CoA by adding a molecule of $\mathrm{CO}_{2}$ to acetyl-CoA. The S-Metolachlor is absorbed through the coleoptiles of grasses and hypocotyl of broadleaves, and operates in the terminal bud in the process of cell division, inhibiting the synthesis of lipids, fatty acids, leaf waxes, terpenes, flavonoids and proteins, interfering with hormonal regulation, inhibiting the apical meristem and root.

The present study had the objective of determining the effects of manual hoeing and herbicides diuron, fluazifop-p-butyl and atrazine
+ S-metolachlor on vegetative growth, yield and quality of pineapple, cultivar 'Pérola'.

\section{MATERIAL AND METHODS}

The experiment was conducted at an experimental area located near the city of Janaúba, Northern Minas Gerais, in the São Francisco Valley, about $100 \mathrm{~km}$ from the Jaíba Project. The area where the experiment has been installed has the following geographic coordinates: $43^{\circ} 16^{\prime} 18.2^{\prime \prime}$ $\mathrm{W}$ and $15^{\circ} 49^{\prime} 51.5^{\prime \prime} \mathrm{S}$, with an altitude of about $540 \mathrm{~m}$. Average rainfall is about $870 \mathrm{~mm}$, average annual temperature is $24{ }^{\circ} \mathrm{C}$, with 2700 hours of sunshine annually and average relative humidity of $65 \%$, being an Aw climate according to Köpen's classification.

The period of the experiment conduction took approximately 20 months. Before planting the seedlings, soil samples were collected for analysis of fertility and texture (Table 2).

The experimental area presents flat topography. The following weeds were found: Amaranthus deflexus (pigweed), Amaranthus spinosus (spiny amaranth), Amaranthus viridis (slender amaranth), Cyperus spp. (sedge), Cyperus esculentus (yellow nutsedge), Commelina benghalensis (day flower), Bidens pilosa (hairy beggarticks), Galinsoga parviflora (gallant soldier), Gnaphalium spicatum (spiked cudweed), Chamaesyce hirta (asthma plant), Brachiaria plantaginea (alexandergrass), Elusine indica (indian goosegrass), Mollugo verticillata (green carpetweed) Cenchrus echinatus (southern sandbur), Portulaca oleracea (little hogweed).

The soil is a quartzipsament, with sandy textural classification. Soil preparation consisted of plowing to a depth of $0.40 \mathrm{~m}$ and chemical fertilization when planting. Fertilization was made with $4 \mathrm{~g}$ per plant of $\mathrm{P}_{2} \mathrm{O}_{5}$ when planting, and $10 \mathrm{~g}$ per plant of $\mathrm{N}$ and $10 \mathrm{~g}$ per plant of $\mathrm{K}_{2} \mathrm{O}$ in coverage, in intervals over five applications: first - 60 days after planting (Oct/2008) and the other applications at intervals of 60 days (Dec/2008; Feb/2009, Apr/2009; Jun/2009), distributed around each plant. After plowing, it was implanted the irrigation system, using micro sprinklers spread evenly in the area, thus irrigating the whole area used to grow the pineapples. The crop was irrigated daily in the morning and evening, based on field capacity of soil and crop demand. It was used the cultivar 'Pérola', which is very suited to the region and has a good acceptance in the domestic market, as well as excellent quality.

The experimental design was randomized blocks (RBD) with four treatments and four 
replications, each treatment consisting of the use of different herbicides for weed control and a control treatment. The experimental plot consisted of ten plants and a double border between treatments.

Weed control (treatments) consisted of the application of different herbicide groups in total area, being the treatments: (T1) manual hoe weeding or control; (T2) herbicide diuron (Diuron Nortox SC 500 ) in post emergence at a concentration of 7.5 $\mathrm{mL} \mathrm{L}^{-1}$; (T3) herbicide fluazifop-p-butyl (Fusilade $250 \mathrm{EW}$ ) in post-emergence at the concentration $1.75 \mathrm{~mL} \mathrm{~L}^{-1}$, and the control with the herbicide (T4) atrazine + S-metolachlor (Primestra GOLD), also in post-emergence, at a concentration of $7.5 \mathrm{~mL} \mathrm{~L}^{-1}$. The herbicides were sprayed using a Jacto ${ }^{\circledR}$ backpack pump with $20 \mathrm{~L}$ of volume, equipped with flat type nozzles (Teejet 80.02) and $275 \mathrm{kPa}$ pressure for herbicide application in total area.

The experiment was established on August 28,2008 . Slips with $40 \mathrm{~cm}$ in length were used, being these the most recommended for pineapple planting. Before planting, a manual hoe weeding was done in the whole area, to eliminate any weeds and avoid early competition. The crop was planted in single row at spacing of $0.80 \times 0.25 \mathrm{~m}$, totaling 50,000 plants ha ${ }^{-1}$.

Until 90 days after planting, the area was maintained without the presence of weeds with the aid of manual hoe weeding. On the same occasion, it was made the first application of herbicides in these plots. Besides this application, there were four more at 150, 190, 220 and 260 days after planting. Always before herbicide application, it was made a manual hoe weeding throughout the area to isolate the effect of such competition with the main crop.

Floral induction was accomplished on the plants that did not flower naturally, at 450 days after planting, using Ethrel ${ }^{\circledR}$. The solution was prepared containing $500 \mathrm{mg} \mathrm{L}^{-1}$ of Ethrel and $2 \%$ urea. Application of $30 \mathrm{~mL}$ of the solution was made on the center of the leaf rosette, for better absorption and flowering stimulation.

After the last flowers closed, the fruits were protected with newspaper sheets to reduce direct sunlight incidence and sunburns. Fruit harvest was carried out every time they presented $50 \%$ of yellow bark.

Evaluations were made, monthly, of characteristics during the vegetative and reproductive phases. Characteristics evaluated during the vegetative phase were: stem diameter (SD), with a digital pachymeter; D-leaf length, with a metric tape; number of emitted leaves and percentage of plants with natural flowering.
Production and quality characteristics evaluated were: average weight of fruits $(\mathrm{kg})$, with and without the crown, using an analytical scale (BK 6000, GEHAKA); length and width of fruits (cm), using a digital pachymeter; numbers of slip, slip-sucker and sucker seedlings; total soluble solids (TSS), obtained by refractometry, expressing the results in ${ }^{\circ} \mathrm{Brix}$; and the $\mathrm{pH}$, using a $\mathrm{pH}$ meter ( $\mathrm{PG}$ 1800, GEHAKA).

Data were interpreted by means of analysis of variance and, when significant effects were observed by the $\mathrm{F}$ test, it was used the Tukey test at $5 \%$ probability or analysis of regression for evaluating the vegetative growth characteristics during time. Statistical analysis was carried out using the Genetic and Statistical Analysis System (SAEG 5.0).

\section{RESULTS AND DISCUSSION}

Results obtained were presented in two phases, being one the vegetative and the other the reproductive.

Within the results obtained on the vegetative phase, there was no effect of herbicide treatments and manual hoe weeding on the number of leaves. Considering the natural flowering, it was the same observed after the tenth month (July) in all treatments, being the peak during the fourteenth month (November).

B. Van de Poel et al. (2009) mention in their research that natural flowering of pineapple occurs, specially, in periods with shorter days and lower temperatures at night, therefore, mainly in the months from June to August. That was evident in this study.

Average values of stem diameter during crop development submitted to different herbicides are shown on figure 1 .

It can be observed that an increase in stem diameter occurred until 330 days (twelfth month) after planting, a period in which flowering starts, evidencing a decrease after this time. The period in which occurs a reduction in the stem diameter corresponds exactly to the period in which occurs the higher flowering of the crop (fourteenth month). This phenomenon can be explained by the fact that, after flowering, the plant translocates most of its photassimilates to the production of flowers and fruits.

The average values of the D-leaf measured during pineapple growth can be observed in figure 2 .

Evaluating the length of the D-leaf, the less old leaf among adult leaves and the most active physiologically, during the growth period of the 
crop, can be observed that a constant increase occurred on it, independent of treatments. However, phytotoxicity symptoms were observed after the first herbicide application, especially on the plants submitted to the herbicide mixture atrazine + S-metolachlor, verifying that the herbicides applied on the crop did not interfere on the final growth of the pineapple.

Catunda et al. (2005), evaluating the effect of herbicide amicarbazone on pineapple growth, cultivar 'Pérola', also did not obtain differences on the D-leaf growth, despite also showing phytotoxicity symptoms in the beginning of the crop development, demonstrating that the damages caused in the first days by the herbicides did not interfere on the final growth of the crop. However, these authors compared the effect the herbicide mixture diuron + paraquat on the crop, demonstrating severe damages to pineapple plants, which caused their death 30 days after treatment.

Lima (2007), evaluating the height of “ $D$ ” and "E" leaves in pineapple, variety MD- II Gold, applying the herbicides diuron + bromacil $(2+2$ $\mathrm{kg} \mathrm{ha}^{-1}$ a.i. $)$, diuron + ametryn $\left(1.5+1.5 \mathrm{~kg} \mathrm{ha}^{-1}\right.$ a.i.) and bromacil + diuron + ametryn $(2+2+0.5$ $\mathrm{kg} \mathrm{ha}^{-1}$ a.i.) found that those promoted significant reductions compared with the control (no herbicide application). It was noted that the average reduction in leaves in relation to the control was, on average, of about 8.8, 9.8 and $5.7 \%$, respectively, characterizing low selectivity.

However, if weeds are not controlled, there will be great competition with the pineapple, since it is a plant that has the Crassulacean Acid Metabolism (CAM), which is characterized by the opening of the stomata during the night and closing them during the day. As a result, this species grows slowly, being less aggressive and less competitive with weeds (OSMOND, 1978). Suffering strong competition with weeds, it is necessary to control, either chemical or mechanical control.

The presence of plants of the genus Cyperus increases the activity of denitrifying bacteria in the root region, reducing the availability of nitrogen in the soil. Cyperus rotundus was the plant that was more competitive with the pineapple for nitrogen, being more expressive at higher density (40 plants per pot). The analysis of weed interference in early growth of pineapple shows that at 30 days after treatment, in a density of 40 plants per pot, Cyperus rotundus and Digitaria horizontalis extract a higher percentage of phosphorus and potassium from the soil, compared to other analyzed nutrients, while Bidens pilosa extract more phosphorus (CATUNDA et al. 2006). The reduction of these and other nutrients interfere with the productivity and fruit quality.

As for the results obtained in evaluating the reproductive phase, there were no variations in quality and production of fruits of the pineapple, cultivar 'Pérola' submitted to treatments with herbicides, even showing phytotoxicity symptoms in plants, mainly in the treatment with atrazine + S-metolachlor (table 2). These results allow to indicate the use of the herbicides used in this study even post-planting and throughout the production cycle of the pineapple, enabling reduction in the cost of weed control and the use of new active principles in integrated management.

Considering the quality aspects weight, length and diameter of the fruit and brix and $\mathrm{pH}$ of the pulp, it was observed that brix and $\mathrm{pH}$ values were above the recommended minimum for fruit harvest, which are indicative of excellent flavor. However, fruits collected showed a weight bellow the classification range or weight of the infrutescence proposed by the General Warehouses Company of the State of São Paulo (CEAGESP). These classifications are based on normative instruction 01, from February $1^{\text {st }}$, 2002, published by the Ministry of Agriculture.

The brix and $\mathrm{pH}$ of the pineapple fruits were not significantly different between treatments, indicating that the herbicides did not change their value of soluble solids and acidity. The values are considered good, indicating that the fruits have excellent flavor.

Reinhardt \& Cunha (1984), evaluating the weight of pineapple fruits to determine the critical period of weed competition, found that without weed control there was no production of fruits with commercial value, and that a control performed after floral differentiation did not increase the size, neither improved the quality of the fruit.

Small fruits have a lower market value and are more difficult to commercialize. However, there are some market trends that choose small fruits with excellent flavor and appearance. The consequence of small fruit was the low yield obtained in all treatments, not exceeding $30 \mathrm{t} \mathrm{ha}^{-1}$. According to Souza \& Cardoso (2001), it is recommended for the fresh fruit market a minimum weight of $1.3 \mathrm{~kg}$, especially during harvest season, because in the period between harvests, fruits of lower weight $(0.9 \mathrm{~kg})$ are also accepted.

Although no treatment effect was detected on natural flowering, the values found are quite high and may explain the production of such small fruits, because of the size of the plants that had not yet reached optimal size for flowering. The expectation 
was to promote the artificial induction of the plants in this study only in mid-2010, producing fruits with good market acceptance at the end of this year. In other studies conducted in the semiarid conditions, and in observations in the preliminary study, the percentage of plants that suffered natural floral induction ranges from 25 to 35 (MAIA, et al. 2009)

It was also noted that the months with higher number of plants with natural flowering were August and September, being an indicative that the months of June and July are those in which environmental conditions favor this phenomenon, agreeing with Carvalho et al. (2005).

Regarding the number of seedlings produced, both slips and suckers, it is considered that the values observed in this study are consistent with the literature (REINHARDT et al., 2003). Production of slip-suckers seedlings was not observed until the end of the evaluations.

TABLE 1 - Climatic data from the Janaúba region during the cultivation, December 2008 to November 2009.

\begin{tabular}{cccccc}
\hline Months 2008/2009 & \multicolumn{6}{c}{ Temperature $\left({ }^{\circ} \mathbf{C}\right)$} & Relative Humidity (\%) & Precipitation (mm) \\
\hline & Min. & Avg & Max. & & 0.0 \\
Aug & 16.3 & 24.1 & 31.9 & 48.6 & 4.4 \\
Sep & 18.3 & 26.1 & 33.9 & 43.1 & 0.0 \\
Oct & 20.1 & 28.0 & 36.0 & 41.8 & 104.4 \\
Nov & 21.6 & 26.3 & 31.1 & 63.8 & 193.9 \\
Dec & 30.5 & 25.5 & 20.5 & 72.8 & 215.6 \\
Jan & 21.0 & 26.6 & 32.2 & 62.9 & 24.8 \\
Feb & 20.6 & 27.0 & 33.4 & 54.0 & 83.2 \\
Mar & 21.1 & 27.3 & 33.5 & 56.9 & 70.9 \\
Apr & 20.8 & 25.7 & 30.6 & 63.4 & 9.1 \\
May & 18.2 & 24.0 & 29.8 & 57.2 & 0.0 \\
Jun & 17.5 & 23.9 & 30.3 & 54.2 & 0.0 \\
Jul & 15.9 & 23.3 & 30.7 & 47.3 & 0.0 \\
Aug & 18.0 & 24.7 & 31.5 & 46.1 & 2.7 \\
Sep & 19.8 & 27.1 & 34.4 & 45.9 & 192.9 \\
Oct & 21.1 & 27.2 & 33.4 & 57.5 & 126.9 \\
Nov & 20.5 & 26.8 & 33.2 & 58.9 & 207.0 \\
Dec & 21.2 & 26.3 & 31.4 & 68.5 & \\
\hline
\end{tabular}

Source: EPAMIG / INMET

TABLE 2 - Results of chemical and physical analysis of the experimental area. Janaúba, MG.

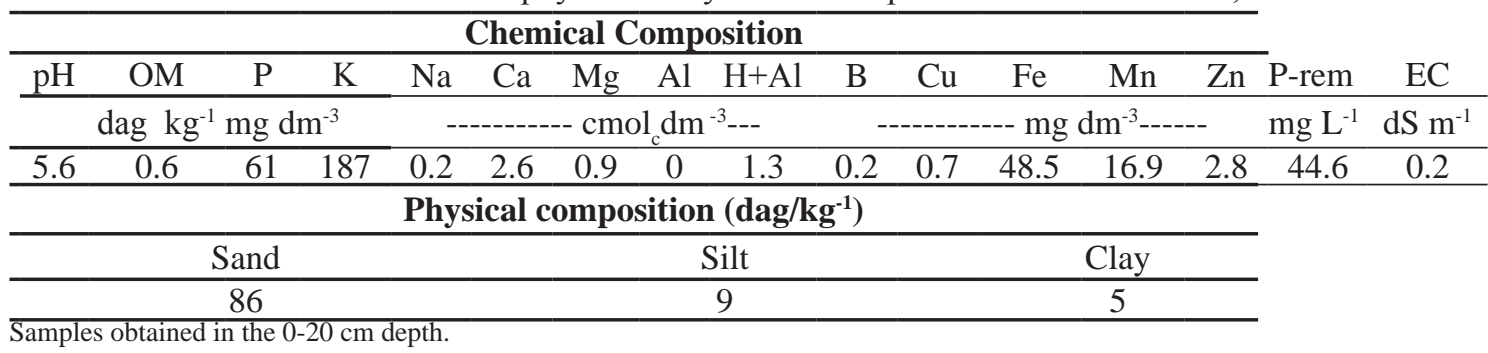

TABLE 3 -Mean values obtained after harvest of fruit weight (g) (FW), fruit weight without the crown (g) (FWWC), fruit length (cm) (LEN), fruit diameter (cm) (DIAM), number of slips (NS), number of suckers (NS), $\mathrm{pH}$ of the pulp $(\mathrm{pH})$, brix of the pulp (BRIX), percentage of plants with natural flowering (PPNF)* and yield ( $\left.\mathrm{t} \mathrm{ha}^{-1}\right)$ (YD).

\begin{tabular}{lcccccccccc}
\hline & FW & FWWC & LEN & DIAM & NS & NS & BRIX & pH & PPNF* & YD \\
\hline Control & 504.7 & 434.0 & 11.34 & 8.07 & 2.6 & 1.0 & 14.7 & 3.7 & 62.5 & 25.2 \\
Diuron & 588.5 & 509.4 & 12.26 & 8.48 & 4.2 & 1.8 & 14.3 & 3.8 & 77.0 & 29.4 \\
Fusilade & 474.2 & 409.8 & 11.58 & 7.96 & 3.1 & 0.9 & 14.2 & 3.8 & 63.3 & 23.7 \\
Primestra & 478.4 & 405.2 & 11.15 & 7.92 & 3.4 & 1.2 & 15.0 & 3.7 & 62.3 & 23.9 \\
\hline Average & 511.5 & 439.6 & 11.58 & 8.11 & 3.3 & 1.2 & 14.6 & 3.7 & 66.3 & 25.6 \\
\hline CV (\%) & 21.32 & 23.36 & 10.55 & 6.02 & 25.56 & 36.60 & 5.60 & 3.60 & 35.94 & 21.32 \\
\hline
\end{tabular}

* obtained at 450 days

No significant effects for these variables were detected according to the Tukey test at $5 \%$. 


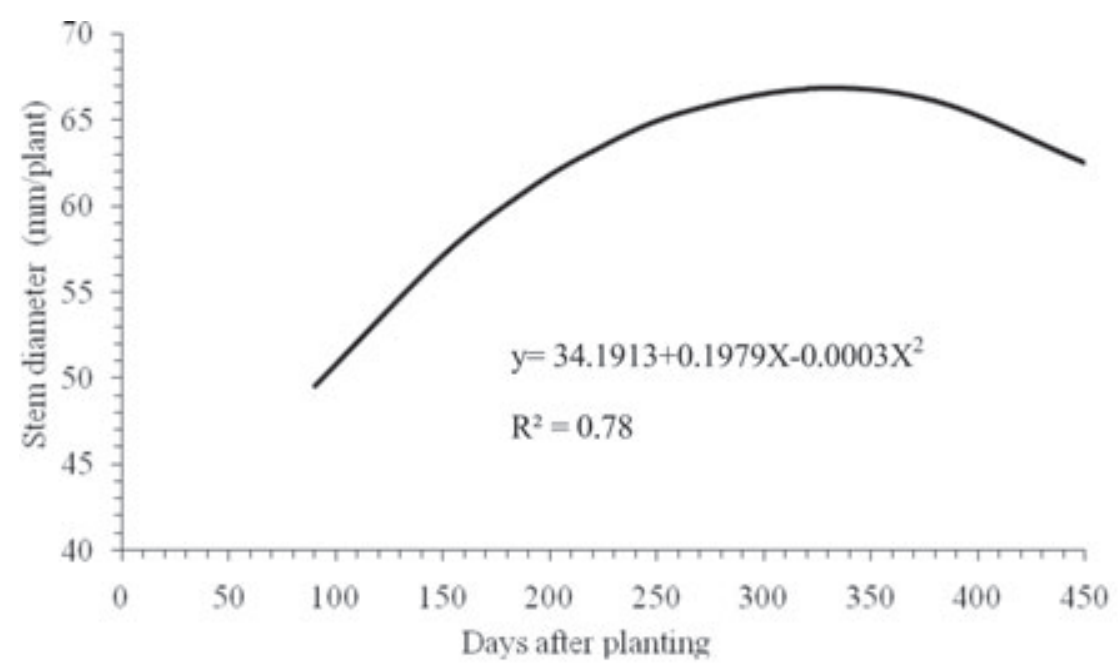

FIGURE 1 - Average values of stem diameter $(\mathrm{mm})$ during growth of pineapple crop.

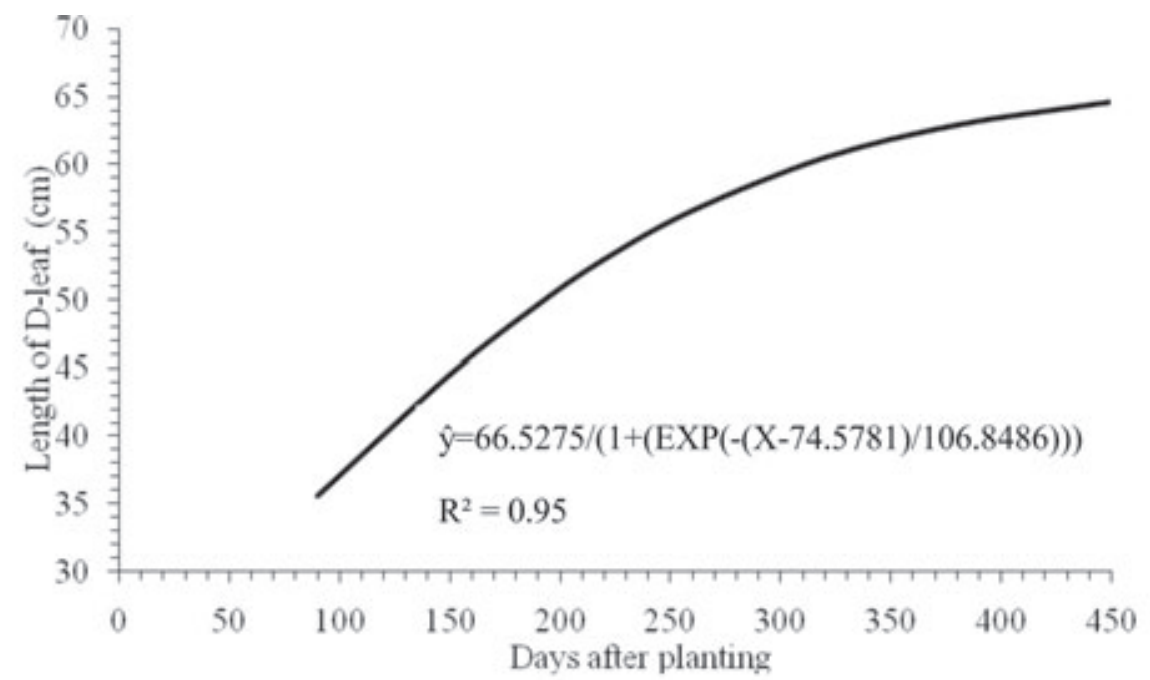

FIGURE 2 - Average values of the D-leaf measured during pineapple growth.

\section{CONCLUSIONS}

Herbicides diuron, fluazifop-p-butyl and atrazine + S-metolachlor, applied during vegetative growth in total area, did not influence production, yield and quality of the pineapple, cultivar 'Pérola'.

\section{ACKNOWLEDGEMENTS}

The authors would like to thank the Fundação de Amparo a Pesquisa do Estado de Minas Gerais - FAPEMIG and Coordenadoria de Aperfeiçoamento de Pessoal de Nível Superior - CAPES, for financial assistance.

\section{REFERENCES}

CARVALHO, S.L.C.; NEVES, C.S.V.J.; BURKLE, R.; MARUR, C.J. Épocas de indução floral e soma térmica do período do florescimento à colheita de abacaxi Smooth Cayenne. Revista Brasileira de Fruticultura. Jaboticabal SP,vol.27, n. 3, p. 430433. dez/ 2005.

CATUNDA, M.G.; FREITAS, S.P.; OLIVEIRA, J.G. and SILVA, C.M.M.. Efeitos de herbicidas na atividade fotossintética e no crescimento de abacaxi (Ananas comossus). Planta daninha. Viçosa MG, vol.23, n.1, pp. 115-121. jan.mar/ 2005 
CATUNDA,M.G;FREITAS,S.P;SILVA,C.M.M;CA RVALHO,A.J.R.C;SOARES,L.M.S. Interferência de plantas daninhas no acúmulo de nutrientes e no crescimento de plantas de abacaxi. Planta Daninha, Viçosa MG,vol.24, n.1.p.199-204. 2006.

CRESTANI, M et al.Ciência Rural, Santa Maria RS, Das Américas para o Mundo - origem, domesticação e dispersão do abacaxizeiro. From the Americas to the World - origin, domestication and dispersion of pineapple v.40, n.6, p.1473-1483, jun, 2010.

FAO, Food and Agriculture Organization of the United Nations. Roma: FAOSTAT Database Gateway-FAO. Disponível em: $<$ http://faostat.fao. org/ > Acesso em: 03 agosto 2010.

IBGE, Instituto Brasileiro Geografia e Estatística. Disponível em: < http://www.ibge.gov.br > Acesso em: 23 julho 2011.

LIMA, G. R. G. Seletividade de espécies de bromeliáceas submetidas á aplicação em pós-emergencia de herbicidas inibidores do fotossistema II. Setembro/2007. Monografia parcial de conclusão do curso de Agronomia. Escola Superior de Agronomia de Paraguaçu Paulista. Paraguaçu Paulista-SP.2007.Disponível em: http://www.ebah. com.br/seletividade-de-especies-bromeliaceassubmetidas-a-aplicacao-em-pos-emergencia-deherbicidas-a52667.html, acesso dia 26 de agosto de 2010.

MAIA,V.M; ALMEIDA JÚNIOR,A.B; MIZOBUTZI,G.P; MIZOBUTZI, E.H; PACHECO,D.D. Fruit and Planting material production by irrigated "Perola" pineapple in repouse to Planting Spacing under semi-arid conditions. Acta Horticulture, V.822, p.125-130, mar/2009.
OSMAND, C.B. Crassulacean Acid Metabolism: A Curiosity in Context Annual Review of Plant Physiology, vol. 29: 379-414, 1978.

REINHARDT, D. H.Controle de Plantas Daninhas. In: REINHARDT, D. H.; SOUZA, L. F. S.; CABRAL, J. R. S. Abacaxi irrigado em condições semi-áridas. Cruz das Almas: EMBRAPA-CNPMF, 2001, p. 50-53.

REINHARDT, D.H.; CABRAL, J.R.S.; SOUZA, L.F.S.,SANCHES, N.F.; MATOS, A. P. Pérola and Smooth Cayene pineapple cultivars in the state of Bahia, Brazil:growth, flowering, pests and diseases, yield and fruit quality aspects. Fruits, Paris, v.57, p.43-53, 2002.

REINHARDT, D. H.; SOUZA, et al. Management of slips and its effect on growth and production of 'pérola' pineapple plants. Revista Brasileira de Fruticultura, Jaboticabal, v. 25, n. 2, p. 248-252. Ago/2003.

REINHARDT,D.H.R.C; CUNHA,G.A.P.da. Determinação do Período Crítico de Competição de Ervas Daninhas na Cultura do Abacaxi Pérola. Pesquisa Agropecuária Brasileira,Brasília V.19, $\mathrm{n}^{\circ}$ 4, p., p.461- 467, abr/1984.

SOUZA, J da S; CARDOSO, C,E,L.Comercialização. In: REINHARDT, D. H.; SOUZA, L. F. S.; CABRAL, J. R. S. Abacaxi irrigado em condições semi-áridas. Cruz das Almas: EMBRAPA-CNPMF, 2001, p. 88-91. 